1 Supplementary Information

2 Biomineralisation of uranium-phosphates fueled by microbial degradation of 3 isosaccharinic acid (ISA)

4 Author list: Gina Kuippers, Katherine Morris, Luke T. Townsend, Pieter Bots, Kristina Kvashnina, Nicholas D.

5 Bryan, Jonathan R. Lloyd

$6 \quad$ Number of pages: 12

7 Contents

8 Section S1: Methodological details 2

9 Section S2: Geochemical Data 3

10 Section S3: XAS \& XRD Spectra $\quad 6$

11 Section S4: Electron Microscopy Data $\quad 9$

12 Section S5: Additional Microbiology Data 11

13 Section S6: References 11 
Calibrated $\mathbf{p H}$ and $\mathbf{E}_{\boldsymbol{h}}$ measurements: The $\mathrm{pH}$ probe was a Mettler Toledo FEP20 digital meter equipped with a Fisherbrand FB68801 electrode and the redox probe a Denver Instrument Accumet digital meter equipped with a Mettler Toledo Inlab Redox Micro ORP.

Inductively-coupled plasma mass spectrometry. Analyses were done on an Agilent $7500 \mathrm{CX}$ (ICP-MS). Samples for ICP-MS were prepared by centrifugation $(14,000 \mathrm{~g}, 10 \mathrm{~min})$ to remove any particles from solution and aliquots of the supernatant were diluted in $2 \% \mathrm{HNO}_{3}$ at the required concentrations $(<100 \mathrm{ppb})$. Standards for uranium were diluted from VWR certified standard dilutions, and were run after every 10 samples.

Ion-exchange chromatography. ISA and organic acids as well as sulfate and phosphate were analysed by using a Dionex ICS5000 Dual Channel system. The instrument was fitted with a Dionex AS-AP auto sampler that was connected to a CD20 conductivity detector. A Dionex Capillary $(50$ x $0.4 \mathrm{~mm})$ AG11-HC $4 \mu \mathrm{m}$ guard column and a Dionex Capillary $(250 \times 0.4 \mathrm{~mm})$ AS11-HC $4 \mu \mathrm{m}$ analytical column were used for these analyses. The mobile phase was concentrated $\mathrm{KOH}$ with high purity water at a flow rate of $0.015 \mathrm{~mL} / \mathrm{min}$ and a backpressure of 3,200 PSI. Background suppression was set at $13 \mathrm{~mA}$. Samples $(0.4 \mu \mathrm{L})$ were injected to a run starting at $1 \mathrm{mM}$ $\mathrm{KOH}$ for 10 minutes, which was increased to $38 \mathrm{mM}$ up to minute 25 and re-equilibrated until 40 minutes. For sulfate and phosphate measurements, the instrument was operated with a Dionex Capillary $(50 \times 2 \mathrm{~mm})$ AG18 guard column and a Dionex Capillary $(250 \times 2 \mathrm{~mm})$ AS18 analytical column. The mobile phase was used as above at a flow rate of $0.025 \mathrm{~mL} / \mathrm{min}$ and a backpressure of 2,100 PSI. Background suppression was set at $23 \mathrm{~mA}$. Samples $(0.1 \mu \mathrm{L})$ were run at $38 \mathrm{mM} \mathrm{KOH}$ for a run-time of 10 minutes.

Sampling regime. The sample volume was in total $1 \mathrm{~mL}$ per time point and bottle, and an additional $1 \mathrm{~mL}$ was removed for X-ray analysis (at 2 time points). This was enough to carry out all analyses and leave approximately $70 \%$ initial volume. From this, $5 \mathrm{~mL}$ were required for XAS analysis at the end of the incubation. 
55 List of sample names. The table contains abbreviations for experiments as they are referred to in the main text 56 and SI information; together with their composition; for a detailed description the reader is referred to the

57 methodological

\begin{tabular}{|c|c|c|c|c|c|}
\hline \multirow[t]{2}{*}{ Experimental name } & \multicolumn{2}{|c|}{ Microbial inoculum } & \multirow{2}{*}{$\begin{array}{l}\text { ISA } \\
\mathbf{m M}\end{array}$} & \multirow{2}{*}{$\frac{\mathrm{Fe}(\mathrm{III})}{\mathrm{mM}}$} & \multirow{2}{*}{$\frac{\mathrm{U}(\mathrm{VI})}{\mathrm{mM}}$} \\
\hline & Alive (\%) & Sterile (\%) & & & \\
\hline ISA-fermenting experiment & 1.0 & - & 3.5 & - & - \\
\hline $\begin{array}{l}\text { ISA-degrading, } \quad \mathrm{Fe}(\mathrm{III}) \text { - } \\
\text { reducing experiment }\end{array}$ & 1.0 & - & 3.5 & 30 & - \\
\hline $\begin{array}{l}\text { No inoculum, abiotic U(VI) } \\
\text { control }\end{array}$ & - & - & 3.5 & - & 1 \\
\hline $\begin{array}{l}\text { No inoculum, abiotic U(VI) }+ \\
\text { Fe(III) control }\end{array}$ & - & - & 3.5 & 30 & 1 \\
\hline $\begin{array}{l}\text { U(VI)-ISA fermentation } \\
\text { experiment }\end{array}$ & 1.0 & - & 3.5 & - & 1 \\
\hline $\begin{array}{l}\text { U(VI)-ISA, Fe(III)-reducing } \\
\text { experiment }\end{array}$ & 1.0 & - & 3.5 & 30 & 1 \\
\hline U(VI)-ISA sterile control & - & 1.0 & 3.5 & - & 1 \\
\hline $\begin{array}{l}\mathrm{U}(\mathrm{VI}) \text {-ISA, Fe(III)-reducing } \\
\text { sterile control }\end{array}$ & - & 1.0 & 3.5 & 30 & 1 \\
\hline $\begin{array}{lrr}\text { Mechanism } & \text { of } & \mathrm{U}(\mathrm{VI}) \\
\text { reduction; } & \text { sterile } & \mathrm{Fe}(\mathrm{III})- \\
\text { reducing incubation } & +\mathrm{U}(\mathrm{VI})\end{array}$ & $\begin{array}{l}1.0 \text { (heat- } \\
\text { sterilized } \\
\text { following } \\
\text { Fe(III) } \\
\text { reduction) }\end{array}$ & - & 3.5 & 30 & $\begin{array}{c}1 \text { (added } \\
\text { after } \\
\text { sterilization) }\end{array}$ \\
\hline $\begin{array}{l}\text { Mechanism of } \mathrm{U}(\mathrm{VI}) \\
\text { reduction; microbially active } \\
\text { Fe(III)-reducing incubation }+ \\
\mathrm{U}(\mathrm{VI})\end{array}$ & 1.0 & - & 3.5 & 30 & 1 \\
\hline
\end{tabular}


60

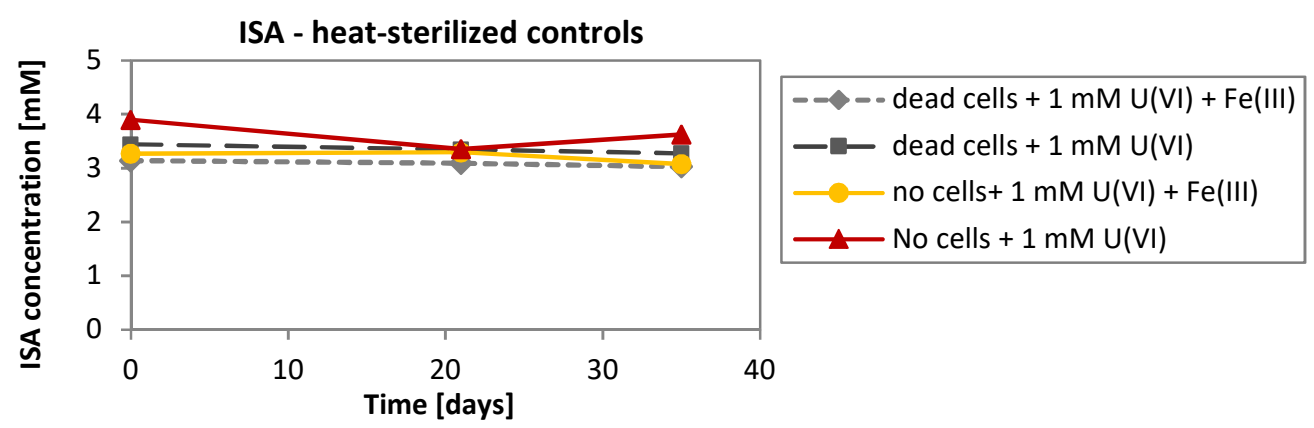

61 Figure S1. Fate of ISA in heat-sterilized control experiments with $1 \mathrm{mM} \mathrm{U}(\mathrm{VI})$ in minimal medium and with or without microbial inoculum, testing abiotic factors that may influence ISA solubility.

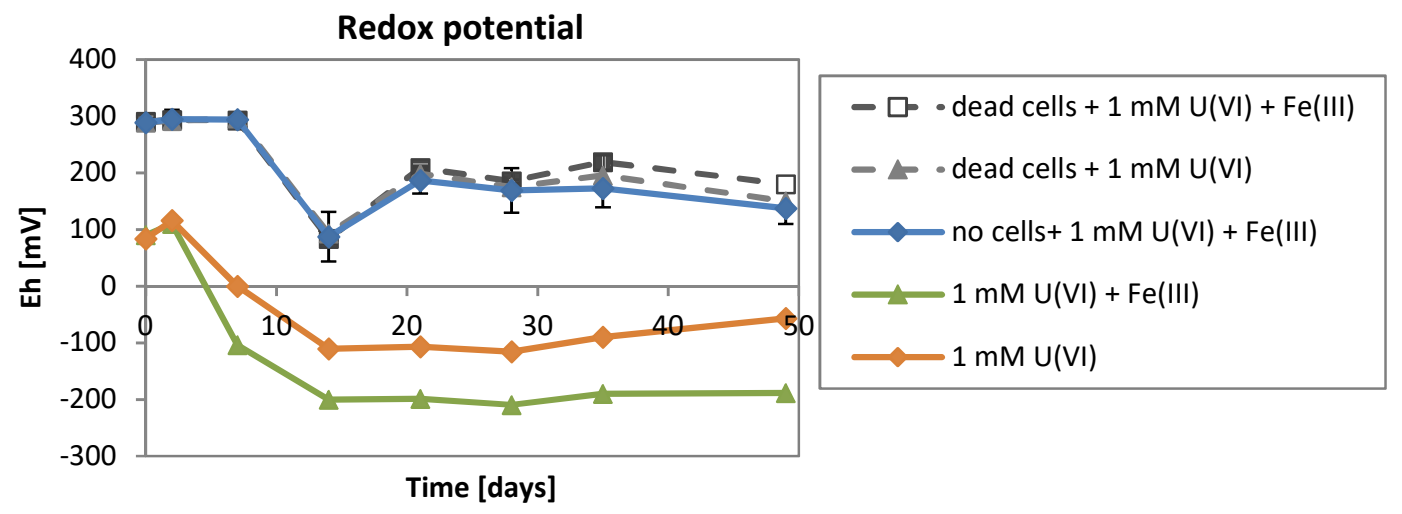

63

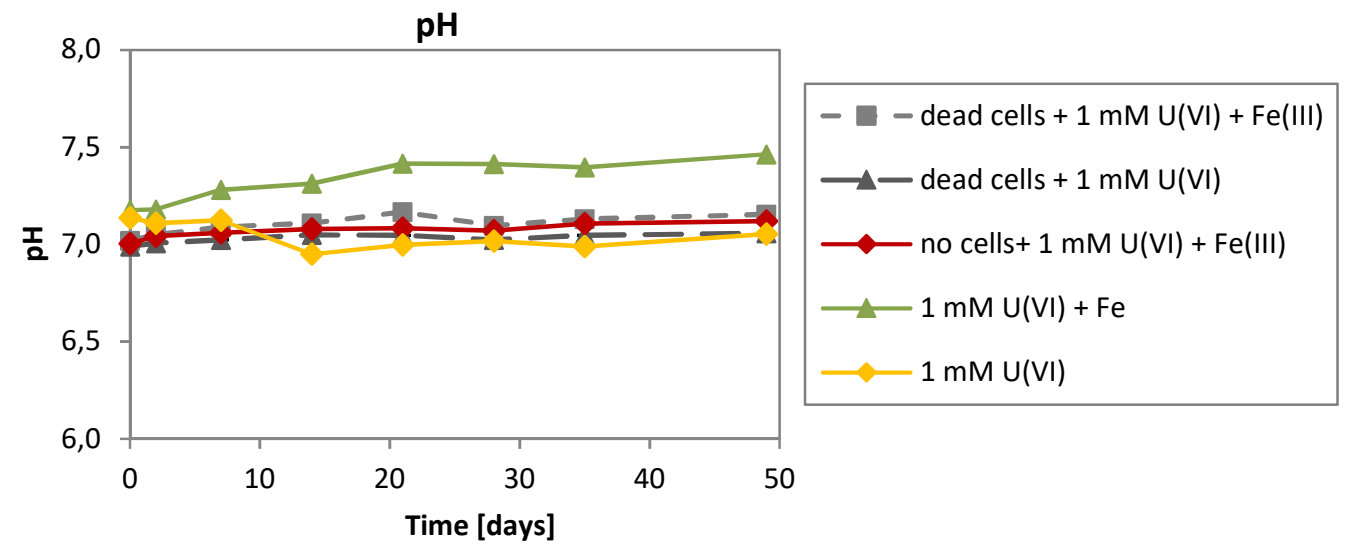

66 Figure S3. pH evolution in U(VI)-ISA degradation experiments with and without added Fe(III), alongside 67 theircontrols. 


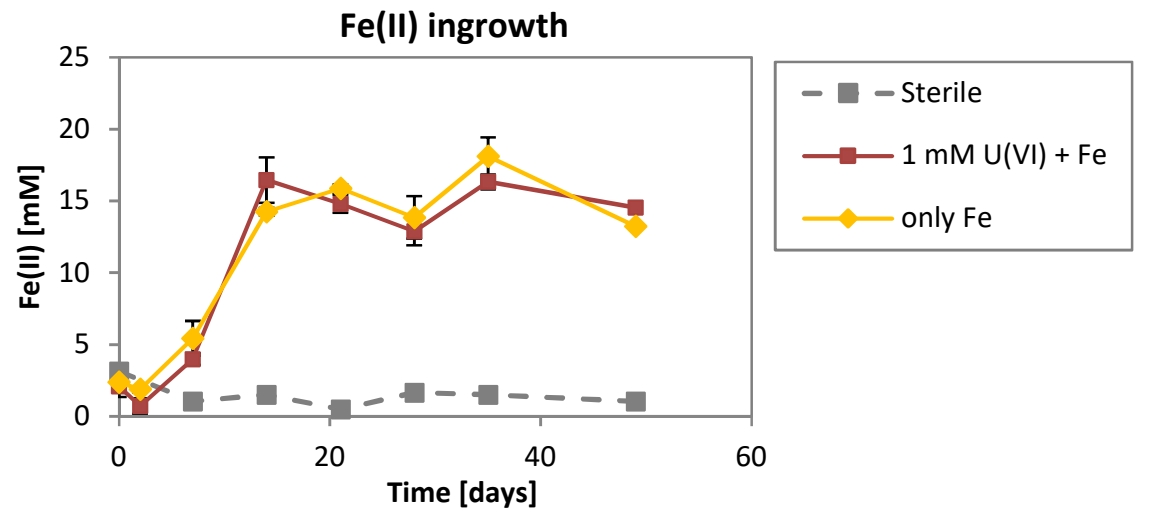

68 Figure S4. Relative Fe(II) ingrowth compared to total HCl-extractable iron measured with the ferrozine assay.

69 Sterile control contains heat-killed microbial inoculum.

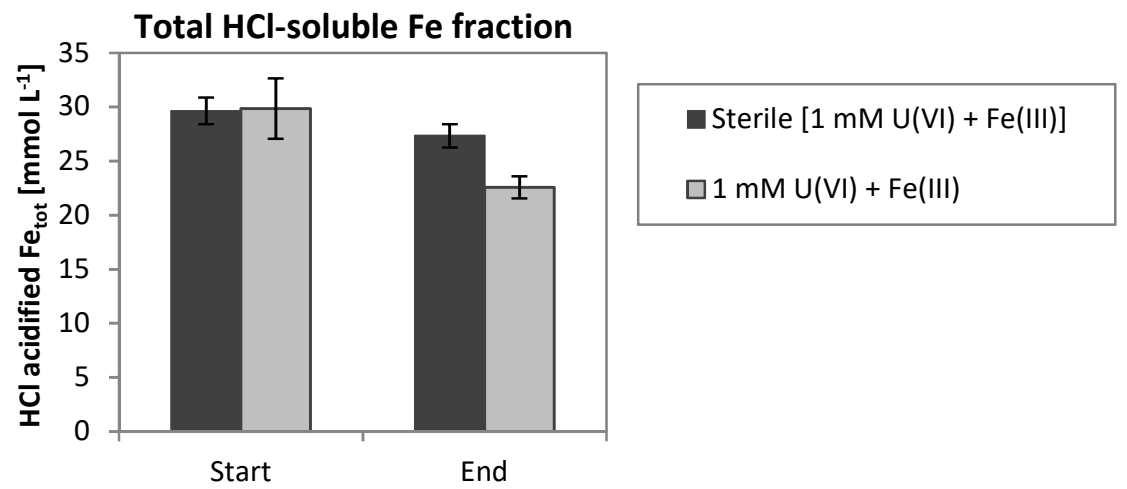

Figure S5. Total $\mathrm{HCl}$-extractable Fe fraction analysed in microcosms by the ferrozine assay after acidification in $0.5 \mathrm{~N} \mathrm{HCl}$ or $0.25 \mathrm{~N}$ hydroxylamine- $\mathrm{HCl}^{1}$. The $\mathrm{Fe}\left(\right.$ oxy)hydroxide concentration was approximately $30 \mathrm{mmol} \mathrm{L}^{-}$
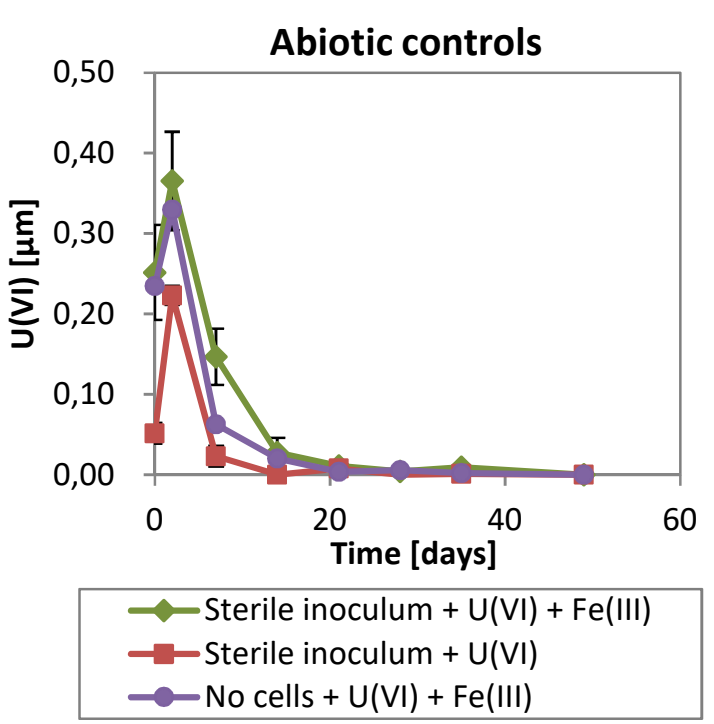

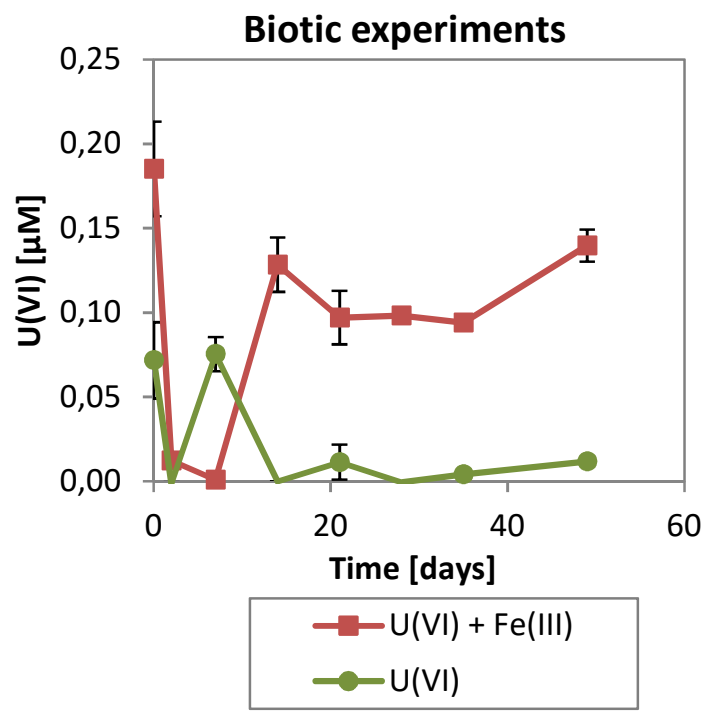

Figure S6. Spectrophotometric quantification of U(VI) using the bromo PADAP assay. Left panel shows abiotic controls containing U(VI) and right panel shows biotic incubations containing U(V). 


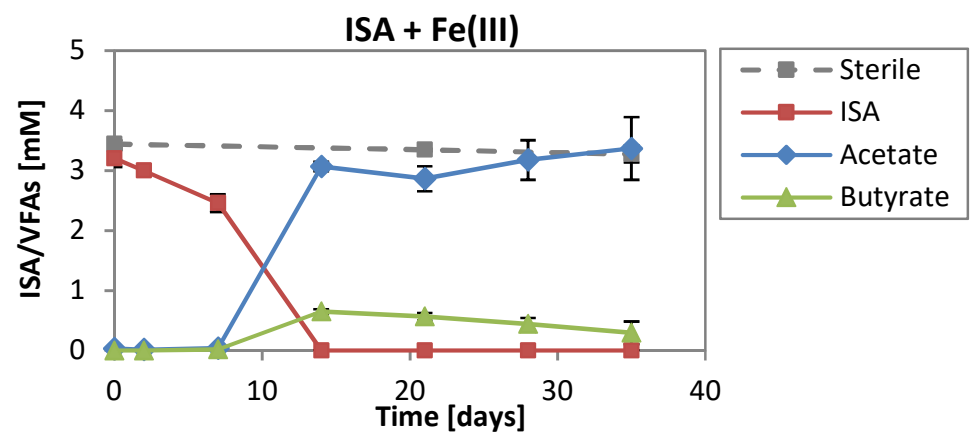

76 Figure S7. ISA-degrading, Fe(III)-reducing experiment as a control to the incubation containing U(VI) which is 77 discussed in the main text. 


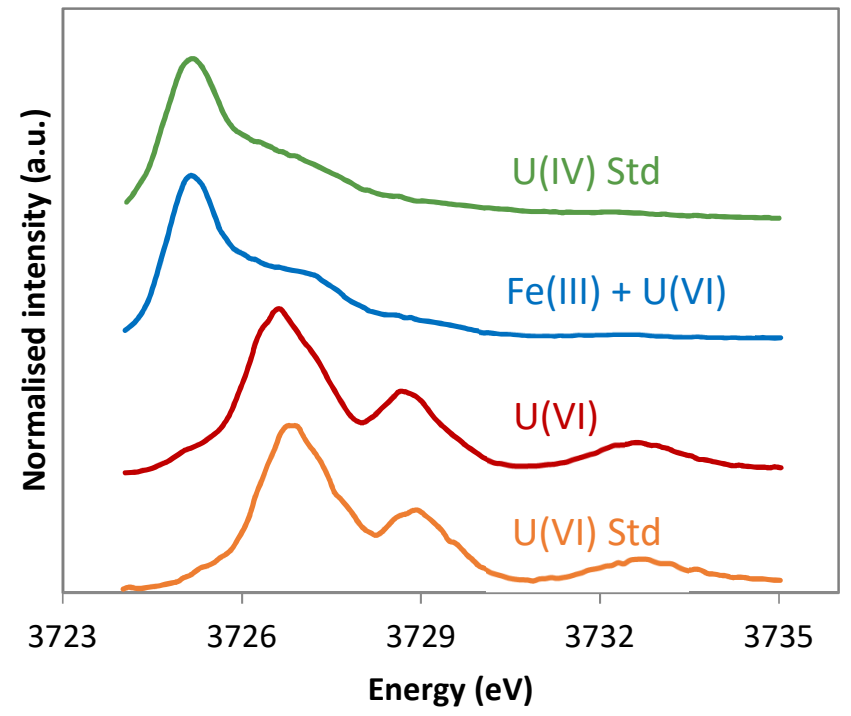

Figure S8. Uranium $\mathrm{M}_{\mathrm{IV}}$-edge high resolution (HR) XANES data collected at beamline ID26 beamline of ESRF, Grenoble, France. Displayed are U(VI)-ISA-fermentation experiment (red) and U(VI)-ISA, Fe(III)-reducting experiment (blue). Alongside standards for U(VI) (green) and U(IV) (orange) are presented, which have been reproduced from Kvashnina et al. ${ }^{2}$ with permission from the authors.

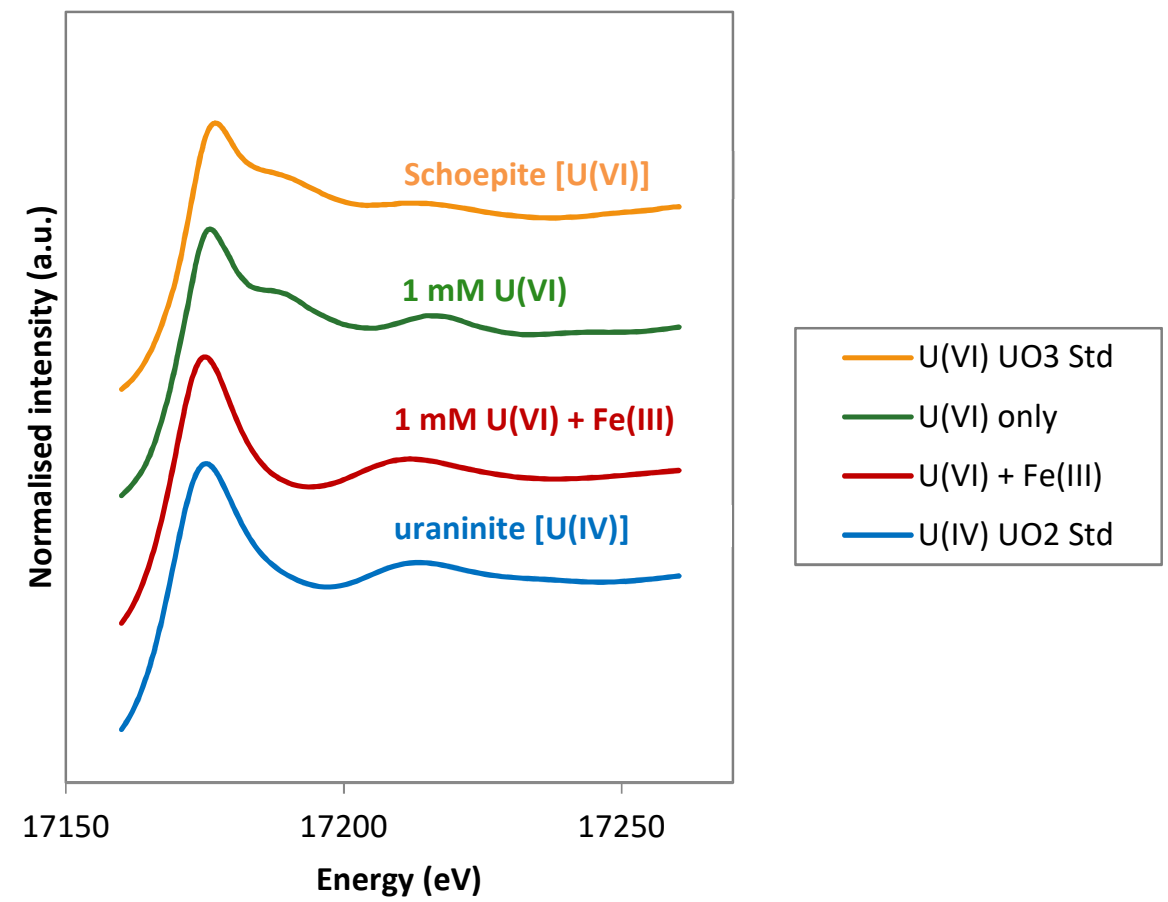

Figure S9. Uranium L LII-edge XANES spectra for U(VI)-ISA-fermentation experiment (green) and U(VI)-ISA, Fe(III)-reducting experiment (red) collected at beamline B18, Diamond Lightsource, Harwell. 


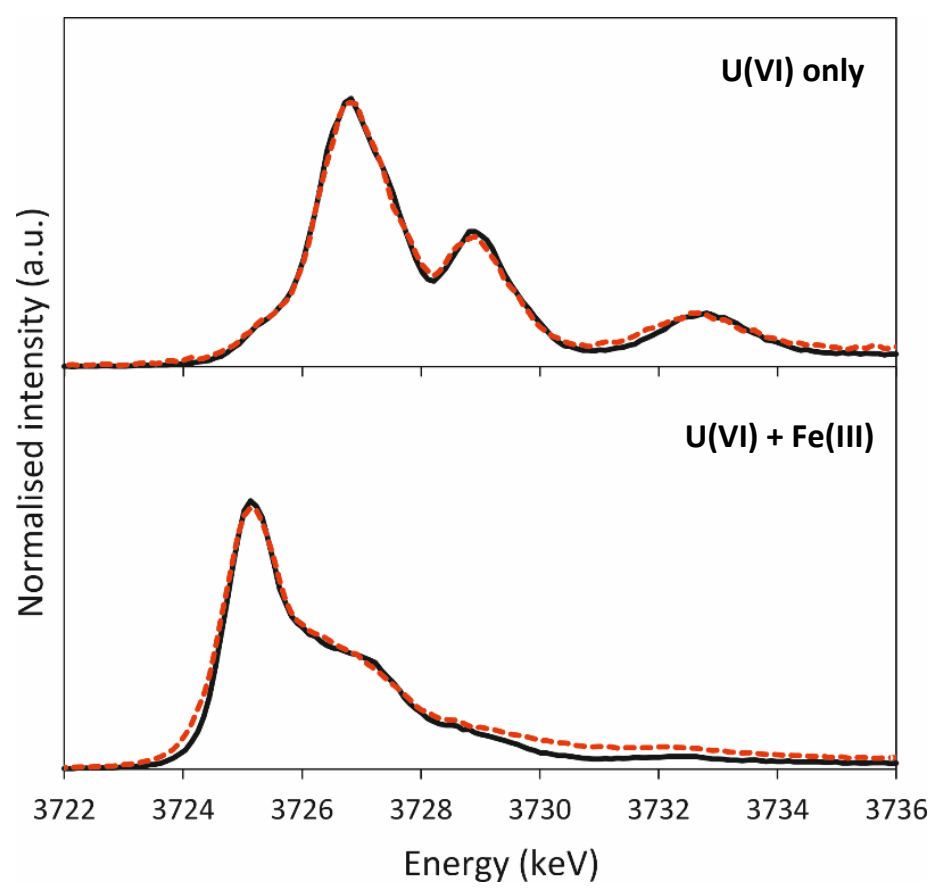

87 Figure S10. Linear combination fitting (LCF) results for Uranium MIV-edge HERFD XANES spectra for U(VI)88 ISA fermentation (top) and U(VI)-ISA, Fe(III)-reducing experiments (bottom) after bioreduction showing the data 89 (black) and linear combination fits (red dashed lines). Data were collected at beamline ID26 beamline of ESRF, 90 Grenoble, France. The spectra for the standards used in this analysis can be found in Roberts et al. ${ }^{3}$.

\begin{tabular}{lcccc}
\hline \multicolumn{5}{c}{ Linear combination fits } \\
\hline Contribution [\%] & VI & V & IV & R-Factor \\
\hline U(VI) only & 98.2 & 0 & 1.8 & 0.0052 \\
U(VI) + Fe(III) & 2.7 & 0 & 97.3 & 0.0155 \\
\hline
\end{tabular}

Table S1: Linear combination fit results for $\mathrm{U}_{4}$-edge HERFD-XANES spectra from Figure S10. All results from linear combination fitting had an R-factor $<0.02$. 


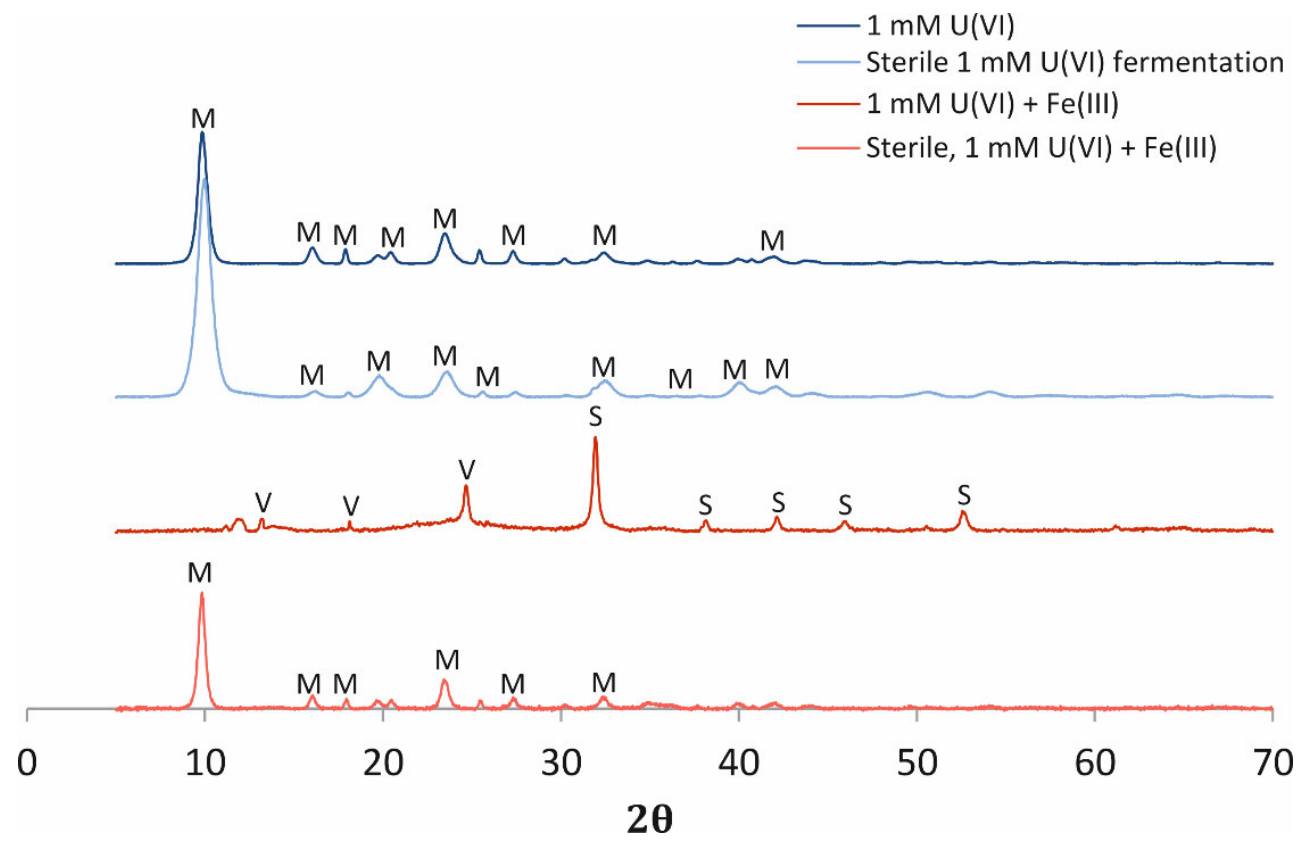

Figure S11. XRD data for U(VI)-ISA fermentation and U(VI)-ISA, Fe(III)-reducing experiments and corresponding sterile controls containing a heat-sterilized microbial inoculum at incubation end $(\mathrm{WL}=1.5406)$. Labels indicate: $(\mathrm{M})$ meta-autunite group (with closest matches for metaankoleite $\left[\mathrm{K}_{2}\left(\mathrm{UO}_{2}\right)_{2}\left(\mathrm{PO}_{4}\right)_{2} \cdot 6\left(\mathrm{H}_{2} \mathrm{O}\right)\right]$ or metanatroautunite $\left.\left[\mathrm{Na}_{2}\left(\mathrm{UO}_{2}\right)_{2}\left(\mathrm{PO}_{4}\right)_{2} \bullet 6\left(\mathrm{H}_{2} \mathrm{O}\right)\right]\right)$, (S) siderite $\left[\mathrm{FeCO}_{3}\right]$, and $(\mathrm{V})$ vivianite $\left[\mathrm{Fe}_{3} \mathrm{PO}_{4} \cdot 8 \mathrm{H}_{2} \mathrm{O}\right]$.

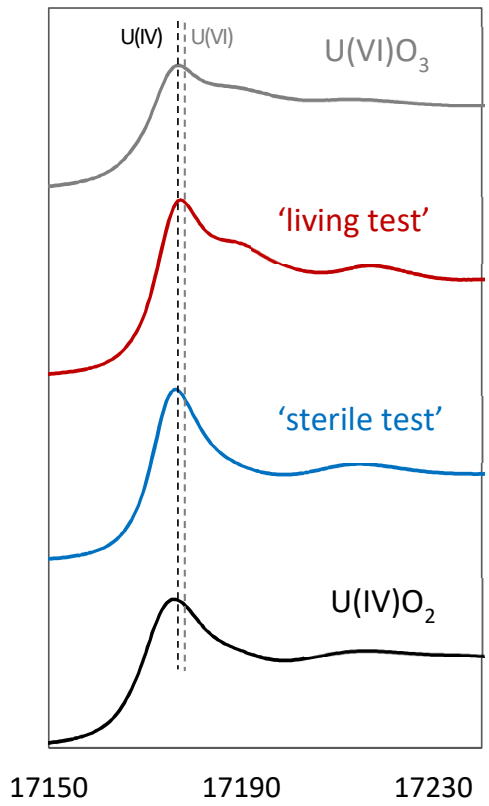

101

Figure S12. U L LII-edge XANES data showing standards for U(IV) and for U(VI) in grey and black, respectively. Samples are ISA-degrading, Fe(III)-reducing experiment, either supplemented with $1 \mathrm{mM} \mathrm{U}(\mathrm{VI})$ following bioreduction (red line) or autoclaved following bioreduction and then supplemented with $1 \mathrm{mM} \mathrm{U}(\mathrm{VI})$ (blue line). 

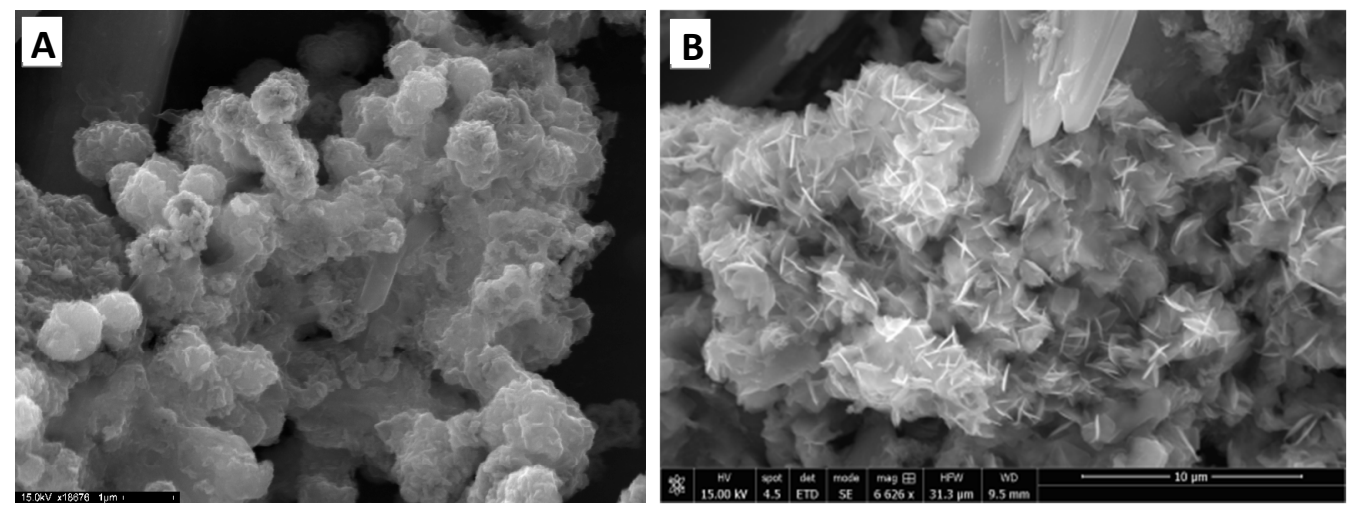

Figure S13. ESEM images showing uranium-containing minerals from the (A) U(VI)-ISA-fermenting experiment that shows spherulitic clusters and (B) U(VI)-ISA, Fe(III)-reducing experiment that comprises needle-like disordered particles.

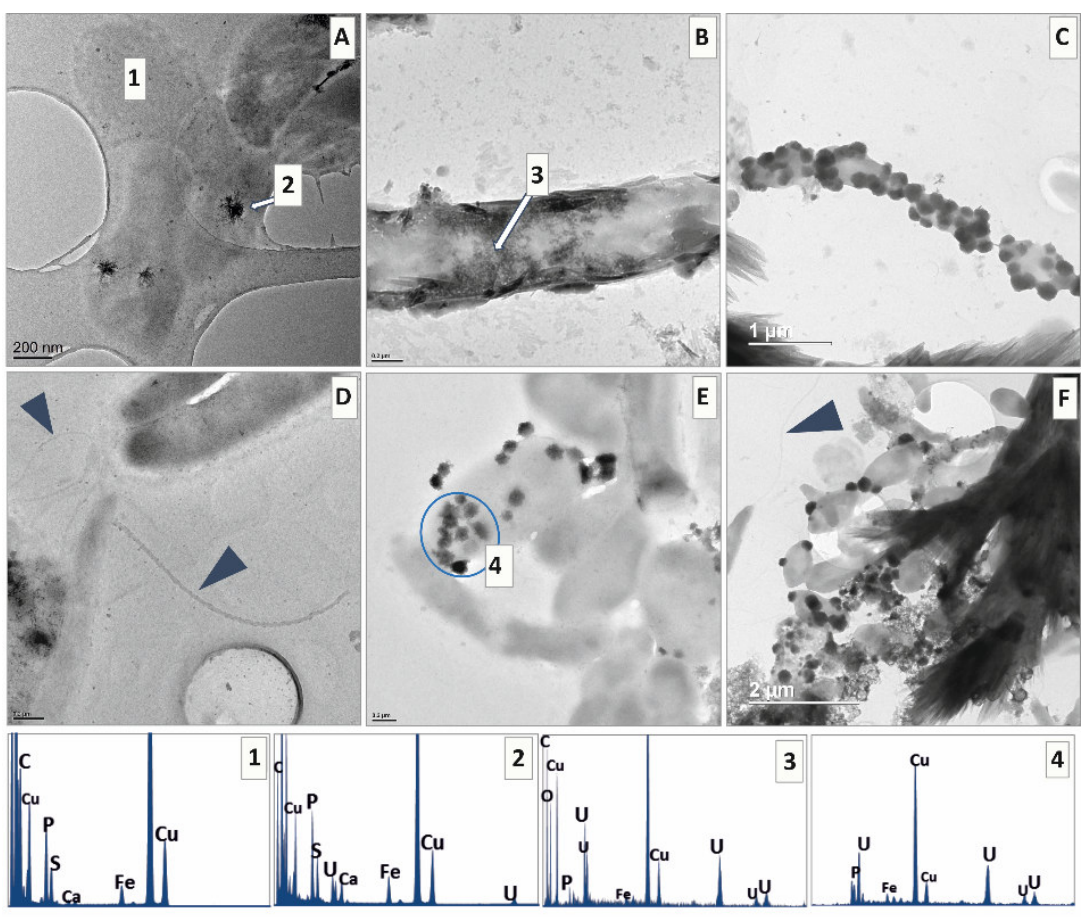

Figure S14. TEM images showing microbial association with biominerals observed in the U(VI)-ISA-fermenting experiment, A: Background EDS of cell (1) compared to clusters of fibrous structures comprising high amounts of $\mathrm{U}(2)$; B: U-rich encrustation of cell; C: U-containing precipitates around cell which could be internal or external; D, E, and F: show clusters of rounded precipitates on cells containing mainly $\mathrm{P}$ and $\mathrm{U}$. 


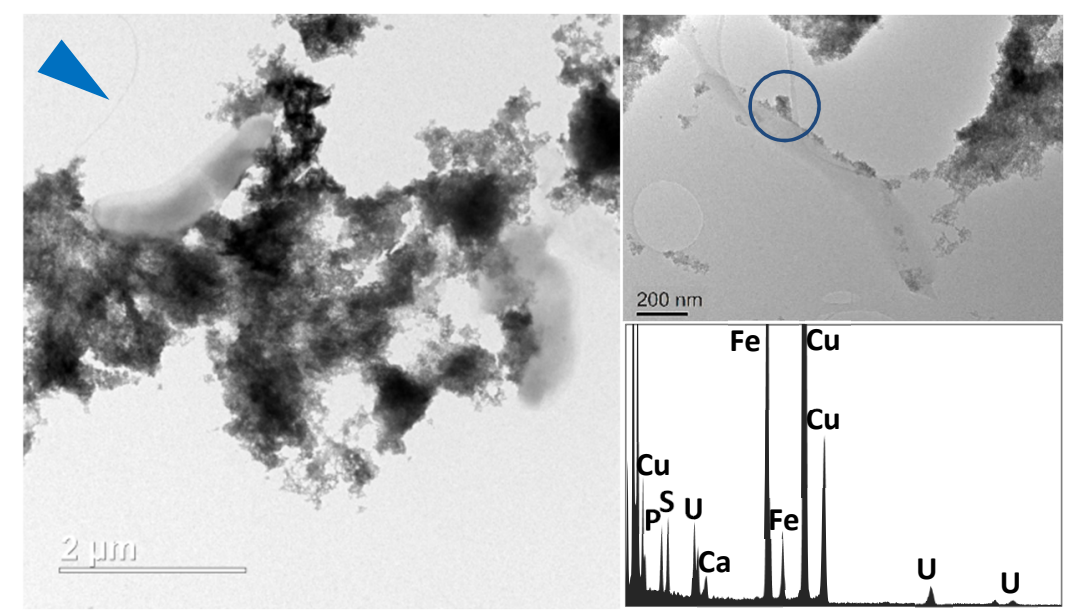

119 Figure S15. TEM images of U(VI)-ISA, Fe(III)-reducing experiment showing microbial cells surrounded by Fe and $\mathrm{U}$ precipitates. Arrow in left image points at what appears like an extracellular appendix. 


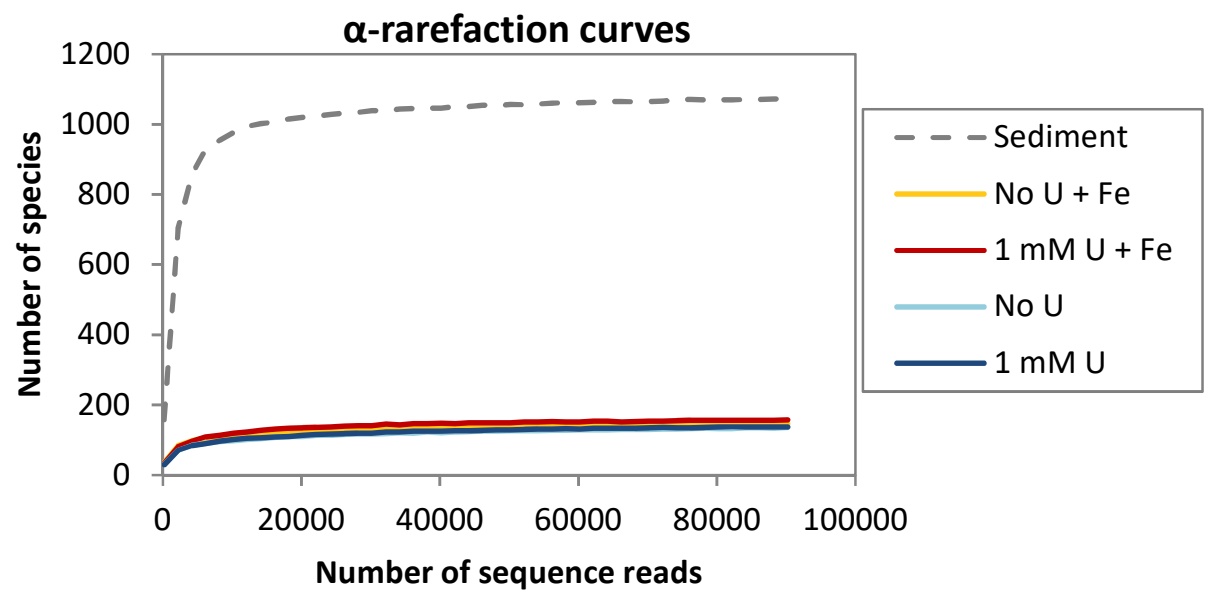

Figure S16. $\alpha$-arefaction curves obtained from 16S rRNA gene sequencing after biodegradation of ISA showing maximum of distinct species per sample.

\section{Section S6: References}

(1) Lovley, D. R.; Phillips, E. J. P. Availability of Ferric Iron for Microbial Reduction in Bottom Sediments of (2) Kvashnina, K. O.; Butorin, S. M.; Martin, P.; Glatzel, P. The Chemical State of Complex Uranium Oxides. Phys. Rev. Lett. 2013, 111 (25), 1-5. https://doi.org/110.1103/PhysRevLett.111.253002.

(3) Roberts, H. E.; Morris, K.; Law, G. T. W.; Mosselmans, J. F. W.; Bots, P.; Kvashnina, K.; Shaw, S. Uranium(V) Incorporation Mechanisms and Stability in Fe(II)/Fe(III) (Oxyhydr)Oxides. Environ. Sci. Technol. Lett. 2017, 4 (10), 421-426. https://doi.org/10.1021/acs.estlett.7b00348. 